\title{
Tumor Protein D53
}

National Cancer Institute

\section{Source}

National Cancer Institute. Tumor Protein D53. NCI Thesaurus. Code C30117.

Tumor protein D53 (204 aa, $22 \mathrm{kDa}$ ) is encoded by the human TPD52L1 gene. This protein plays a role in apoptosis. 